\title{
Health status of Chrysichthys nigrodigitatus in response to aquatic pollution in Epe, Lagos and Ologe Lagoons, Southwest Nigeria
}

\author{
Kingsley Chukwuemeka Kanu ${ }^{1 *}$, Emmanuel Taiwo Idowu² \\ ${ }^{1}$ Department of Environmental Management and Toxicology, Michael Okpara University of Agriculture, PMB 7267 Umudike, Nigeria \\ ${ }^{2}$ Department of Zoology, University of Lagos PMB 56, Akoka, Nigeria \\ ${ }^{*}$ Corresponding author, E-mail: kanukc@gmail.com
}

\begin{abstract}
The aquatic ecosystem is frequently the final recipient of pollutants, which may be hazardous to aquatic organism. In this study, in 2012 the following factors were examined: level of $\mathrm{Pb}, \mathrm{Ni}, \mathrm{Cd}$ and $\mathrm{Zn}$ in water, sediments, and liver, tissue and gills of Chrysichthys nigrodigitatus from Epe, Lagos and Ologe Lagoon. Superoxide dismutase, catalase, gluthathione peroxidase activity, gluthathione and thiobarbituric acid-reacting substance concentrations in fish samples were also determined, and liver histopathology was conducted. A condition factor for fish was also determined. The results revealed higher levels of $\mathrm{Zn}$ in water samples from Lagos lagoon compared to Epe lagoon. $\mathrm{Ni}$ and $\mathrm{Cd}$ in tissue of samples from Lagos and Ologe Lagoon respectively and $\mathrm{Pb}$ in samples from both lagoons were higher than the FAO 1983 limit. Glutathione concentration was higher at Lagos lagoon $\left(0.84 \pm 0.55 \mu \mathrm{mol} \mathrm{mL}^{-1}\right)$ compared to Ologe $(0.72 \pm 0.62$ $\left.\mu \mathrm{mol} \mathrm{mL} \mathrm{m}^{-1}\right)$. Vacuolar degeneration and bile stains were observed in liver of fish samples from Lagos and Ologe lagoon, respectively. The study showed that $C$. nigrodigitatus is adversely affected by pollutants in the lagoons.
\end{abstract}

Key words: antioxidants, biomarkers, Chrysichthys nigrodigitatus, condition factor, heavy metals, histopathology, oxidative stress. Abbreviations: BAF, bio accumulation factor ; BSAF, biota-sediment accumulation factor; CAT, catalase; CF, condition factor; DO, dissolved oxygen; GPOx, gluthathione peroxidase; GSH, glutathione; SOD, superoxide dismutase; TBARS, thiobarbituric acid-reacting substances; TDS, total dissolved solids.

\section{Introduction}

All over the world, aquatic pollution is a major concern. Over 400 million tons of chemical products are discharged from domestic, agricultural and industrial activities into aquatic ecosystems (Schwarzenbach et al. 2006). Trace metals such as $\mathrm{As}, \mathrm{Hg}$, Se, Cd, Ni, Pb, Cr, Mo, Sb, Zn, Cu, Mn and $\mathrm{Ni}$ are discharged into the aquatic environment from coalburning power plants, iron and steel plants, non-ferrous metals smelters, domestic effluents and sewage sludge disposal (Nriagu et al. 1988). In the aquatic environment, trace metals are not degraded and due to their affinity for biomolecules such as lipids and amino acids, they accumulate in cells of phytoplankton and zooplankton. In this way, high concentrations of the metals in organisms can be found on tops of food chain. Considering that the aquatic environment is the final sink of trace metals and chemical products, the essential ecological services provided by fish i.e. nutrient cycling, regulation of trophic structure, aquatic food web dynamics, and carbon flux (Holmlund, Hammer 1999) may be affected.

Fish health can be adversely affected by temperature changes, habitat deterioration and aquatic pollution (Skouras et al. 2003). Fish species have attracted consi- derable interest in studies assessing the biological effects of environmental contaminants (Powers 1989). The ability of fishes to accumulate pollutants in their cells, tissues or body fluids and respond to these pollutants, some times in a specific way, makes them valuable biomonitoring tools for water quality assessment. Fishes may also accumulate trace metals to a level that may pose health risk to the fish and humans via dietary intake. Biomarkers have often been employed to assess the health status of organisms and can serve as early-warning indicators of the effects of environmental pollution (Payne et al. 1987). Biomarkers are measureable biological responses that may indicate exposure to and/or effects from anthropogenic substances at sub-lethal concentrations. A number of biochemical, physiological, enzyme and immune assays are considered suitable markers of exposure to and effects of aquatic contamination (Zelikoff et al. 2000; Skouras et al. 2003; Farombi et al. 2007; Olarinmonye et al. 2009; Obiakor et al. 2010).

The lagoons in Lagos State Nigeria are the final sink of effluents from over 2000 medium and large-scale industries. Also, the Ogun River discharges its municipal waste water into the lagoons (Uaboi-Egbenni et al. 2010). There has been a decline in artisanal fishery in Lagos and 
deteriorating water quality was reported by Oribhabor and Ezenwa (2005) as one of the factors responsible. Among the fish species present in the lagoons, silver catfish is in high demand and remains a commercially important source of revenue for fishermen in Nigeria and West Africa. The fish is also a vital source of animal protein in the human diet. The discharge of effluents into the lagoons may affect vital physiological process, cause stress or organ damage and ultimately affect the fish population. Thus, the aim of the study was to assess the health condition of silver cat fish, evaluate their biological responses to water contamination and determine if heavy metalconcentrations present in the fish were within the recommended limits for human consumption.

\section{Materials and methods}

\section{Description of the study area}

Lagos State, which is located in Southwest Nigeria lies approximately at longitude $2^{\circ} 42^{\prime} \mathrm{E}$ and $3^{\circ} 22^{\prime}$ East respectively and between Latitude $6022^{\prime} \mathrm{N}$ and $6042^{\prime} \mathrm{N}$. Epe, Lagos and Ologe Lagoons (Fig. 1) are among the four major lagoons in Lagos State, Southwest Nigeria (KumoluJohnson et al. 2010). Epe lagoon lies between longitudes $6^{\circ} 33.710^{\prime} \mathrm{N}, 4^{\circ} 03^{\prime} .710^{\prime} \mathrm{E}$ and latitudes $6^{\circ} 31.893^{\prime} \mathrm{N}$, $3^{\circ} 31.912^{\prime}$ E. It has a surface area of about $243 \mathrm{~km} 2$ with a maximum depth of about $2.8 \mathrm{~m}$ (Edokpayi et al. 2008). The lagoon is the major source of water for the inhabitants of Epe and other villages situated along its bank. Lagos lagoon lies between latitude $6^{\circ} 26^{\prime}$ to $6^{\circ} 37^{\prime} \mathrm{N}$ and longitude $3^{\circ} 23^{\prime}$ to

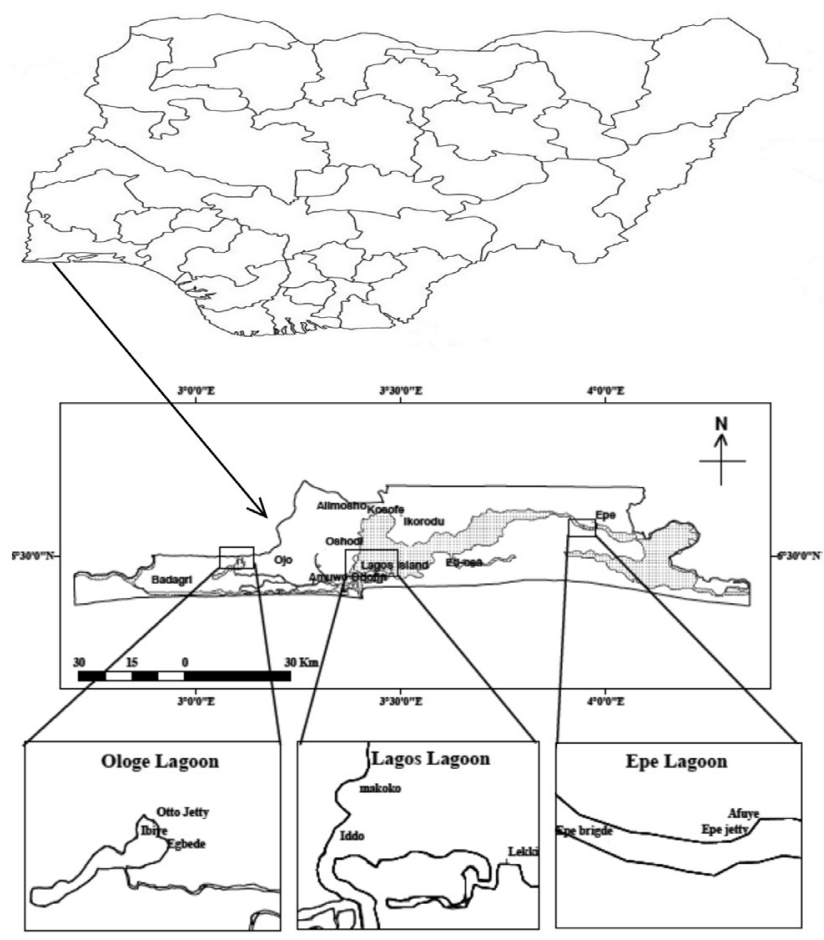

Fig. 1. Map of Nigeria, Lagos State showing the Lagoons and sampling areas. $4^{\circ} 20^{\prime} \mathrm{E}$. Its brackish nature is a consequence of the influence of tidal sea water incursion and freshwater discharge from the adjoining rivers and creeks (Ajao). It provides place of abode for the Ilajes and Ijaws, means of livelihood for fishermen and inland waterway transportation. The lagoon is often used as an open dump for municipal solid waste, disposal of raw human faeces and sinks for residential and commercial effluent (Nubi et al. 2008). Ologe Lagoon lies between longitudes $20^{\circ} 42^{\prime}$ to $4^{\circ} 42^{\prime} \mathrm{E}$ and latitude $6^{\circ} 22^{\prime}$ to $6^{\circ} 42^{\prime} \mathrm{N}$. It sustains a thriving artisanal fisheries industry and serves as a source of water for domestic and industrial use, transportation, logging and sand dredging (Anetekhai et al. 2003). Fishing activity is affected by effluents from Agbara industrial estate and the flushing of solid wastes from river Owo into Ologe lagoon (Adebola 2011). Epe Lagoon was selected as a control because it is relatively unpolluted, given the minimal number of commercial and industries around the lagoon, compared to Lagos and Ologe Lagoon. In each of the lagoons, three sampling points were chosen for the study, namely; Afuye, Epe Jetty and Epe Bridge at Epe lagoon, Makoko, Iddo and Lekki at Lagos lagoon and Otto Jetty, Egbede and Ibiye at Ologe lagoon. The sampling points were chosen because of ease of accessibility. They also represent a source of pollution to the lagoons.

\section{Sample collection}

A total of ninety samples of silver catfish, Chrysichthys nigrodigitatus (Lacépède: 1803), i.e. thirty per lagoon were collected between May and July, 2012. No sex selection was made. Fishes were purchased live from catches of local fishermen at Afuye, Makoko and Otto Jetty which were the fish landing sites of Epe, Lagos and Ologe lagoons respectively. Fishes with no external abnormalities were selected. The fish were sacrificed by a pre-occipital severance of the spinal cord. The weight in grams ( $g$ ) of each specimen was taken using a digital weighing balance, which was wiped dry between samples. Standard length and total length was measured in centimeter $(\mathrm{cm})$ using a meter ruler. They were then dissected, the liver, tissues and gills excised, weighed and then stored at $-10{ }^{\circ} \mathrm{C}$ prior to analysis.

Surface water and bottom sediment samples were collected once monthly between May and July 2012 at each sampling site. The water and sediments from the lagoons were mixed together to form a composite sample for analysis. Water samples were collected by dipping four liter plastic bottles straight into the water. The containers were rinsed three times with the site water prior to collection. All samples were collected in triplicate. Bottom sediment samples were collected using a grab sampler and transferred into polyethylene bags. Samples were transported to the laboratory within $4 \mathrm{~h}$ for heavy metal analysis.

\section{Analytical procedures}

Water temperature, $\mathrm{pH}$, electrical conductivity, dissolved 
oxygen (DO), and total dissolved solids (TDS) were measured in situ using appropriate portable meters: HM Digital COM 100 for temperature and TDS, DO meter (DO5519) and Hanna pH tester.

The concentrations of lead, nickel cadmium, and zinc were determined using an atomic absorption spectrophotometer (Analyst Perkin-Elmer).

For analysis, $5 \mathrm{~mL}$ of concentrated hydrochloric acid was added to $250 \mathrm{~mL}$ of water samples and evaporated to $25 \mathrm{~mL}$. The concentrate was transferred to a $50 \mathrm{~mL}$ flask and diluted to mark with distilled water for the determination of the heavy metals.

Samples $(5 \mathrm{~g})$ of sediment were transferred into $150 \mathrm{~mL}$ conical flasks containing $50 \mathrm{~mL} 0.1 \mathrm{M} \mathrm{HCl}$. The flask was agitated on an orbital shaker for $30 \mathrm{~min}$ and then filtered into $50 \mathrm{~mL}$ standard flask and made up to mark with $0.1 \mathrm{M}$ $\mathrm{HCl}$ for the determination of the heavy metals.

Tissues and organs were defrosted for $2 \mathrm{~h}$. Two g each of liver and gill sample as well as $5 \mathrm{~g}$ of tissue was digested using nitric acid $(10 \mathrm{~mL})$. The samples were heated until brown fumes disappeared and then allowed to cool. Distilled water was added to make up to $50 \mathrm{~mL}$ in a standard volumetric flask. The filtrates were filtered off and then the heavy metal concentrations were determined.

For each lagoon, nine liver samples were analysed for antioxidant activity and lipid peroxidation. The liver of the fish were rinsed in buffered saline. Liver samples $(1 \mathrm{~g})$ were homogenized with $9.0 \mathrm{~mL} 4.0 \mathrm{~m}$ phosphate buffer $\mathrm{pH}$ 8.0. Superoxide dismutase (SOD) activity was determined by measuring the inhibition of auto-oxidation of epinephrine at $\mathrm{pH} 10.2$ at $30^{\circ} \mathrm{C}$ (Magwere et al. 1997). One unit of SOD activity was defined as the amount of SOD necessary to cause 50\% inhibition of epinephrine auto-oxidation. The assay was performed in $3.0 \mathrm{~mL} 50 \mathrm{mM} \mathrm{Na}_{2} \mathrm{CO}_{3}$ buffer to which $0.02 \mathrm{~mL}$ of the sample was added. Epinephrine stock solution $(0.03 \mathrm{~mL})$ was added to the above before taking absorbance readings at $480 \mathrm{~nm}$ for 3 to $5 \mathrm{~min}$. The activity of SOD was expressed as units per min per mg protein.

Catalase (CAT) was assayed colorimetrically at $620 \mathrm{~nm}$ and expressed as $\mu$ moles of $\mathrm{H}_{2} \mathrm{O}_{2}$ consumed per min per $\mathrm{mg}$ protein (Sinha 1972). The reaction mixture $(1.5 \mathrm{~mL})$ contained $1.0 \mathrm{~mL} 0.01 \mathrm{M} \mathrm{pH} 7.0$ phosphate buffer, $0.1 \mathrm{~mL}$ liver homogenate and $0.4 \mathrm{~mL} 2 \mathrm{M} \mathrm{H}_{2} \mathrm{O}_{2}$. The reaction was stopped by the addition of $2.0 \mathrm{~mL}$ dichromate acetic acid reagent (5\% potassium dichromate and glacial acetic acid were mixed in 1:3 ratio). The unit of expression of CAT activity was $\mu \mathrm{mol} \mathrm{H}_{2} \mathrm{O}_{2}$ per min per mg protein.

Glutathione peroxidase (GPOx) activity was measured by the method described by Ellman (1959). Reaction mixture contained $0.2 \mathrm{~mL} 0.4 \mathrm{M}$ phosphate buffer $\mathrm{pH} 7.0$, $0.1 \mathrm{~mL} 10 \mathrm{mM}$ sodium azide, and $0.2 \mathrm{~mL}$ liver homogenate. The contents were incubated at $37{ }^{\circ} \mathrm{C}$ for $10 \mathrm{~min}$. The reaction was stopped by adding $0.4 \mathrm{~mL} 10 \%$ trichloroacetic acid, and centrifuged. Concentration of reduced glutathione in the reaction mixture was measured as described further.
The unit of expression of GPOx activity was $\mu$ mol per mL.

Reduced glutathione (GSH) was determined by the method of Ellman (1959). To the liver homogenate $10 \%$ trichloroacetic acid was added and centrifuged. Supernatant $(1.0 \mathrm{~mL})$ was treated with $0.5 \mathrm{~mL}$ of Ellmans reagent (19.8 mg 5,5-dithio-bisnitro benzoic acid in 100 $\mathrm{mL} 0.1 \%$ sodium nitrate) and $3.0 \mathrm{~mL}$ phosphate buffer $(2 \mathrm{M}$ $\mathrm{pH}$ 8.0). The absorbance was read at $412 \mathrm{~nm}$. The unit of expression was $\mu \mathrm{mol} \mathrm{GSH}$ per $\mathrm{mL}$.

Lipid peroxidation as indicated by the formation of thiobarbituric acid-reacting substances (TBARS) was determined by the method of Nichens and Samuelson (1968). Liver homogenate $(0.1 \mathrm{~mL})$ was treated with 2 $\mathrm{mL}$ (1:1:1 ratio) TBA-TCA-HCl reagent (thiobarbituric acid $0.37 \%, 0.25 \mathrm{M} \mathrm{HCl}$ and $15 \%$ trichloroacetic acid) and placed in water bath for $15 \mathrm{~min}$, cooled and centrifuged at room temperature for $10 \mathrm{~min}$ at $3000 \mathrm{rpm}$. The absorbance of clear supernatant was measured against a blank at 535 $\mathrm{nm}$. The unit of expression of TBARS was nmol per $\mathrm{mL}$.

Bio accumulation factor (BAF) and biota-sediment accumulation factor (BSAF) were determined by the following equations.

$\mathrm{BAF}=$ mean concentration of heavy metal in fish $(\mathrm{mg}$ $\left.\mathrm{kg}^{-1}\right) /$ mean concentration of heavy metal in water $(\mathrm{mg}$ $\mathrm{L}^{-1}$,

$\mathrm{BSAF}=$ mean concentration of heavy metal in fish $(\mathrm{mg}$

$\mathrm{kg}^{-1}$ ) / mean concentration of heavy metal in sediment $\left(\mathrm{mg} \mathrm{kg}^{-1}\right)$.

Thirty fishes per lagoon were used to evaluate the condition factor of the fishes. The condition factor $(\mathrm{CF})$ was calculated according to the following equation (Busacker et al. 1990):

$$
C F=\frac{W}{L^{3}} \times 100
$$

where $W$ is fish wet weight $(\mathrm{g}), L$ is fish total length $(\mathrm{cm})$.

Nine liver samples per lagoon were examined for tissue damage. Liver samples were cut into thin slices of about 0.3 to $0.5 \mathrm{~cm}$ with a scalpel blade, fixed in $10 \%$ formal saline for $6 \mathrm{~h}$ and then dehydrated in graded alcohol; $70 \%$ alcohol for $1 \mathrm{~h}, 90 \%$ alcohol I for $1 \mathrm{~h}, 90 \%$ alcohol II for $1 \mathrm{~h}, 90 \%$ alcohol III for $2 \mathrm{~h}$, absolute alcohol I for $2 \mathrm{~h}$, and absolute alcohol for $3 \mathrm{~h}$. The dehydrated specimens were transferred into xylene 1 for 1 , and then to xylene II for $2 \mathrm{~h}$, followed by wax impregnation and embedding in paraffin for histopathological examination. The resulting sections were mounted on glass microscope slides and air dried prior to staining using hematoxylin and eosin stain, and cover slipped (Luna 1992). Stained sections were then examined using light microscopy.

\section{Data analysis}

The mean values of the of heavy metal concentrations in the gill, liver and muscle of the fish and the mean SOD and CAT activity, and GSH, TBARS and GPOx concentrations 
Table 1. Physicochemical parameters and fish biometrics in three lagoons. The results of fish biometrics are mean \pm SD for 30 fishes per lagoon. Same letter indicate significant difference of the parameter between the lagoons $(p<0.05) .{ }^{*}$ above WHO guideline for $\mathrm{Pb}(0.01$ $\left.\mathrm{mg} \mathrm{L}^{-1}\right)$, \# above the WHO guideline for $\mathrm{Ni}\left(0.02 \mathrm{mg} \mathrm{L}^{-1}\right)$, + below the WHO guideline for $\mathrm{Zn}\left(3 \mathrm{mg} \mathrm{L}^{-1}\right)$

\begin{tabular}{|c|c|c|c|c|}
\hline & Parameter & Epe & Lagos & Ologe \\
\hline \multirow[t]{7}{*}{ Water } & $\mathrm{pH}$ & $7.4 \pm 0.4$ & $7.7 \pm 0.5$ & $7.3 \pm 0.3$ \\
\hline & TDS $\left(\mathrm{mg} \mathrm{L}^{-1}\right)$ & $144 \pm 26$ & $245 \pm 128$ & $75 \pm 5$ \\
\hline & $\mathrm{DO}\left(\mathrm{mg} \mathrm{L}^{-1}\right)$ & $7.10 \pm 0.15$ & $6.90 \pm 0.04$ & $7.10 \pm 0.25$ \\
\hline & Temperature $\left({ }^{\circ} \mathrm{C}\right)$ & $26.8 \pm 1.3$ & $27.4 \pm 1.0$ & $27.4 \pm 0.8$ \\
\hline & $\mathrm{Pb}\left(\mathrm{mg} \mathrm{L}^{-1}\right)$ & $0.009 \pm 0.001$ & $0.015 \pm 0.01^{*}$ & $0.011 \pm 0.01^{\star}$ \\
\hline & $\mathrm{Ni}\left(\mathrm{mg} \mathrm{L}^{-1}\right)$ & $0.011 \pm 0.001 \#$ & $0.010 \pm 0.01 \#$ & $0.016 \pm 0.002 \#$ \\
\hline & $\mathrm{Zn}\left(\mathrm{mg} \mathrm{L}^{-1}\right)$ & $0.13 \pm 0.03 a+$ & $0.29 \pm 0.07 a+$ & $0.14 \pm 0.04+$ \\
\hline \multirow[t]{3}{*}{ Sediment } & $\mathrm{Pb}\left(\mathrm{mg} \mathrm{kg}^{-1}\right)$ & $0.03 \pm 0.03$ & $0.06 \pm 0.02$ & $0.05 \pm 0.04$ \\
\hline & $\mathrm{Ni}\left(\mathrm{mg} \mathrm{kg}^{-1}\right)$ & $0.02 \pm 0.01$ & $0.03 \pm 0.01$ & $0.04 \pm 0.02$ \\
\hline & $\mathrm{Zn}\left(\mathrm{mg} \mathrm{kg}^{-1}\right)$ & $0.58 \pm 0.05$ & $1.23 \pm 0.03$ & $0.32 \pm 0.03$ \\
\hline \multirow[t]{8}{*}{ Fish biometrics } & Total length $(\mathrm{cm})$ & $22.2 \pm 2.1 \mathrm{ab}$ & $19.7 \pm 1.58 \mathrm{ac}$ & $17.3 \pm 2.2 \mathrm{bc}$ \\
\hline & Minimum total length $(\mathrm{cm})$ & 18.0 & 16.0 & 14.0 \\
\hline & Maximum total length $(\mathrm{cm})$ & 27.0 & 23.0 & 21.0 \\
\hline & Standard length $(\mathrm{cm})$ & $17.0 \pm 1.4$ & $15.3 \pm 1.3$ & $13.3 \pm 1.6$ \\
\hline & Minimum standard length & 14.0 & 12.0 & 11.0 \\
\hline & Maximum standard length & 21.0 & 18.0 & 17.0 \\
\hline & Weight $(\mathrm{g})$ & $118.2 \pm 31.6$ & $79.1 \pm 14.8$ & $55.2 \pm 18.5$ \\
\hline & Condition Factor & $1.10 \pm 0.13$ & $1.04 \pm 0.14$ & $1.04 \pm 0.12$ \\
\hline
\end{tabular}

in liver from the different lagoons was compared using ANOVA while Tukeys post hoc test was used to obtain the specific significant differences among the lagoons. Analysis was computed with Statistical Package for Social Sciences (SPSS) version 19.

\section{Results}

\section{Physiochemical parameters of the lagoons and fish} biometrics

The result of the physiochemical parameters of the lagoon
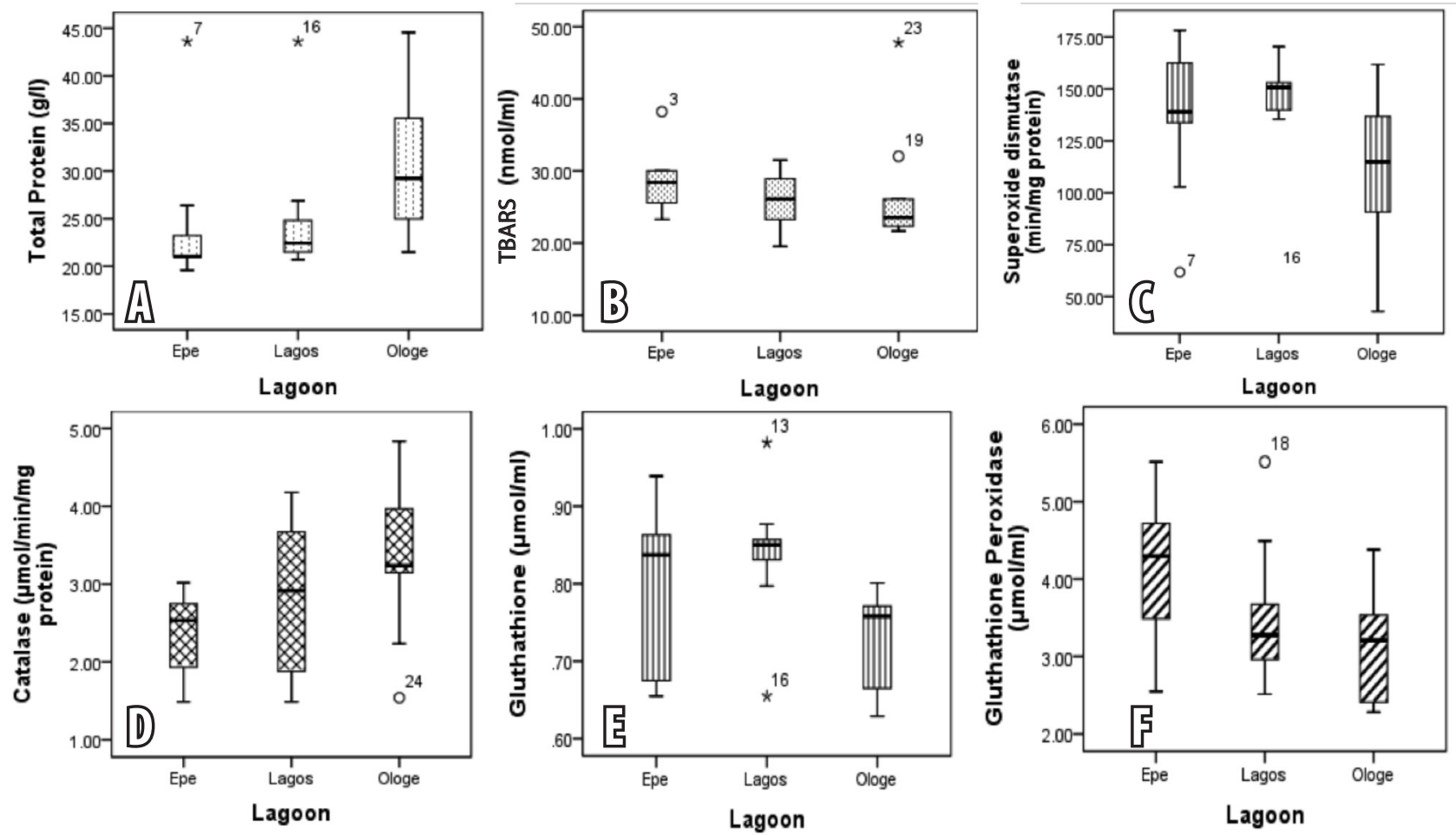

Fig. 2. Comparison of total protein concentration (A), TBARS concentration (B), superoxide dismutase activity (C), catalase activity (D), glutathione concentration (E), glutathione peroxidase activity $(\mathrm{F})$ in liver of fish samples from different lagoons. 
and fish biometrics is presented in Table $1 . \mathrm{Zn}$ had the highest concentration, while Cd was not detected in both water and sediments from the lagoons. Lagos lagoon had the highest concentration of $\mathrm{Pb}$ and $\mathrm{Zn}$ in water and sediment, while $\mathrm{Ni}$ was highest in water and sediment samples from Ologe. Epe lagoon had the lowest concentration of these metals in water and sediments, except compared with $\mathrm{Zn}$ concentration in sediments from Ologe lagoon. $\mathrm{Zn}$ was found to be significantly higher in water samples from Lagos lagoon compared to Epe lagoon.

Lower total length, weight and condition factor of $C$. nigrodigitatus were observed in Ologe and Lagos lagoon compared to Epe Lagoon, but these differences were not statistically significant. The trend of the condition factor of the silver catfish was Epe (1.10) > Lagos (1.04) = Ologe (1.04).

\section{Total protein, antioxidant activity and lipid peroxidation in \\ C. nigrodigitatus}

The activities of antioxidant enzymes in liver of $C$ nigrodigitatus from the lagoons are presented in Fig. 2A to $F$. No statistically significant difference was observed in the level of total protein, activity of superoxide dismutase, catalase, gluthathione peroxidase and level of lipid peroxidation in the liver of $C$. nigrodigitatus sampled from the three lagoons. The trend of total protein level of silver catfish was Ologe $>$ Lagos $>$ Epe lagoon, while the following trend was observed for antioxidant activities: Epe > Lagos $>$ Ologe (SOD); Ologe > Lagos > Epe lagoon (CAT); Epe $>$ Lagos > Ologe lagoon (GPOx) and Epe > Lagos > Ologe lagoons (TBARS). However, gluthathione concentration in liver of samples from Lagos lagoon was higher $(p<0.05)$ than in Ologe lagoon and the trend observed was Lagos $>$ Epe $>$ Ologe lagoon.

\section{Bioaccumulation of heavy metals, BAF and BSAF in C. nigrodigitatus}

A similar trend of accumulation of heavy metal concentration (liver $>$ muscle $>$ gill, liver $>$ gill $>$ muscle, liver $>$ gill $>$ muscle, for $\mathrm{Pb}, \mathrm{Ni}$, and $\mathrm{Zn}$, respectively) was observed in C. nigrodigitatus samples from Epe and Ologe lagoon, while for samples from Lagos lagoon the trend differed (gill $>$ muscle $>$ liver, liver $>$ muscle $>$ gill and gill $>$ muscle $>$ liver for $\mathrm{Pb}, \mathrm{Ni}$ and $\mathrm{Zn}$, respectively) (Table 2 ). $\mathrm{Cd}$ accumulation was similar in the three lagoons, liver > muscle $>$ gill. There were no significant difference in the level of $\mathrm{Pb}, \mathrm{Ni}, \mathrm{Cd}$, and $\mathrm{Zn}$ in the liver, gills and muscle of $C$ nigrodigitatus sample from Lagos and Ologe lagoon compared to Epe lagoon $(p>0.05)$. However, $\mathrm{Pb}$ in liver of fishes from Lagos lagoon was found to be significantly lower compared to fishes sampled from Epe lagoon. $\mathrm{Ni}$ concentration in the liver of fishes from Ologe lagoon was also significantly higher compared to samples from Lagos lagoon, while $\mathrm{Zn}$ in liver of the fishes across the three lagoons differed significantly and the trend was
Ologe $>$ Epe $>$ Lagos. BAF and BSAF, which estimate metal concentrations in fish relative to water and sediments, were highest for liver samples obtained from Epe and Ologe lagoon, unlike Lagos lagoon where BAF and BSAF were highest for gills, except for $\mathrm{Ni}$, which accumulated more in tissue relative to water and sediments.

Table 2. Mean heavy metal concentration $\left(\mathrm{mg} \mathrm{kg}^{-1}\right)$ in gill, muscle and liver of Chrysichthys nigrodigitatus, BAF and BSAF. +, indicates significantly different from gill and muscle; ${ }^{*}$, significantly different from liver and tissue. ND, not determined; a, significantly different from Lagos and Ologe Lagoon; b, significantly different from Epe and Lagos lagoon; $c$, significantly different in all three lagoons ( $p$ $<0.05)$; $\mathrm{z}$, indicates above the Food and Agriculture Organisation (FAO) maximum allowable limits; $\mathrm{Pb}\left(0.5 \mathrm{mg} \mathrm{kg}^{-1}\right), \mathrm{Cd}(0.05 \mathrm{mg}$ $\left.\mathrm{kg}^{-1}\right)$ and $\mathrm{Ni}\left(0.1 \mathrm{mg} \mathrm{kg}^{-1}\right)$ (FAO 1983)

\begin{tabular}{|c|c|c|c|c|}
\hline Lagoon & Metal & Gill & Muscle & Liver \\
\hline \multirow[t]{12}{*}{ Epe } & $\mathrm{Pb}$ & $0.33 \pm 0.26$ & $0.43 \pm 0.34$ & $1.77 \pm 0.47+a$ \\
\hline & BAF & 37.0 & 47.5 & 196.9 \\
\hline & BSAF & 11.1 & 14.3 & 59.1 \\
\hline & $\mathrm{Ni}$ & $0.63 \pm 0.49$ & $0.48 \pm 0.39$ & $2.95 \pm 0.64+$ \\
\hline & BAF & 60.0 & 43.7 & 268.2 \\
\hline & BSAF & 12.5 & 49.6 & 59.0 \\
\hline & $\mathrm{Zn}$ & $1.25 \pm 0.92$ & $0.92 \pm 0.88$ & $4.32 \pm 1.79+c$ \\
\hline & BAF & 9.7 & 7.1 & 33.2 \\
\hline & BSAF & 2.2 & 7.5 & 7.5 \\
\hline & $\mathrm{Cd}$ & $0.02 \pm 0.04$ & $0.03 \pm 0.05$ & $4.32 \pm 1.79+c$ \\
\hline & BAF & ND & ND & ND \\
\hline & BSAF & ND & ND & ND \\
\hline \multirow[t]{12}{*}{ Lagos } & $\mathrm{Pb}$ & $2.80 \pm 2.49^{*}$ & $0.64 \pm 0.75 z$ & $0.21 \pm 0.19^{*}$ \\
\hline & BAF & 138.7 & 42.7 & 14.6 \\
\hline & BSAF & 34.7 & 10.7 & 13.7 \\
\hline & $\mathrm{Ni}$ & $0.89 \pm 0.49$ & $1.24 \pm 1.04 \mathrm{z}$ & $2.04 \pm 1.60$ \\
\hline & BAF & 87.9 & 123.7 & 204.3 \\
\hline & BSAF & 22.0 & 30.9 & 22.0 \\
\hline & $\mathrm{Zn}$ & $5.30 \pm 4.28$ & $2.89 \pm 2.43$ & $2.22 \pm 1.13 c$ \\
\hline & BAF & 18.1 & 9.9 & 7.6 \\
\hline & BSAF & 4.3 & 2.4 & 1.8 \\
\hline & $\mathrm{Cd}$ & $0.022 \pm 0.04$ & $0.032 \pm 0.05$ & $0.04 \pm 0.07$ \\
\hline & BAF & ND & ND & ND \\
\hline & BSAF & ND & ND & ND \\
\hline \multirow[t]{12}{*}{ Ologe } & $\mathrm{Pb}$ & $0.12 \pm 0.12$ & $0.23 \pm 0.19$ & $1.16 \pm 1.42+$ \\
\hline & BAF & 10.6 & 20.7 & 105.9 \\
\hline & BSAF & 12.3 & 4.6 & 23.3 \\
\hline & $\mathrm{Ni}$ & $0.79 \pm 0.81$ & $0.57 \pm 0.68 z$ & $3.43 \pm 1.09+b$ \\
\hline & BAF & 49.8 & 35.9 & 214.4 \\
\hline & BSAF & 19.9 & 14.4 & 85.7 \\
\hline & $\mathrm{Zn}$ & $1.93 \pm 1.93$ & $1.33 \pm 1.49$ & $9.92 \pm 2.30+C$ \\
\hline & BAF & 13.9 & 9.5 & 71.4 \\
\hline & BSAF & 6.1 & 4.1 & 31.0 \\
\hline & $\mathrm{Cd}$ & $0.27 \pm 0.06$ & $0.06 \pm 0.09 z$ & $0.01 \pm 0.02$ \\
\hline & BAF & ND & ND & ND \\
\hline & BSAF & ND & ND & ND \\
\hline
\end{tabular}



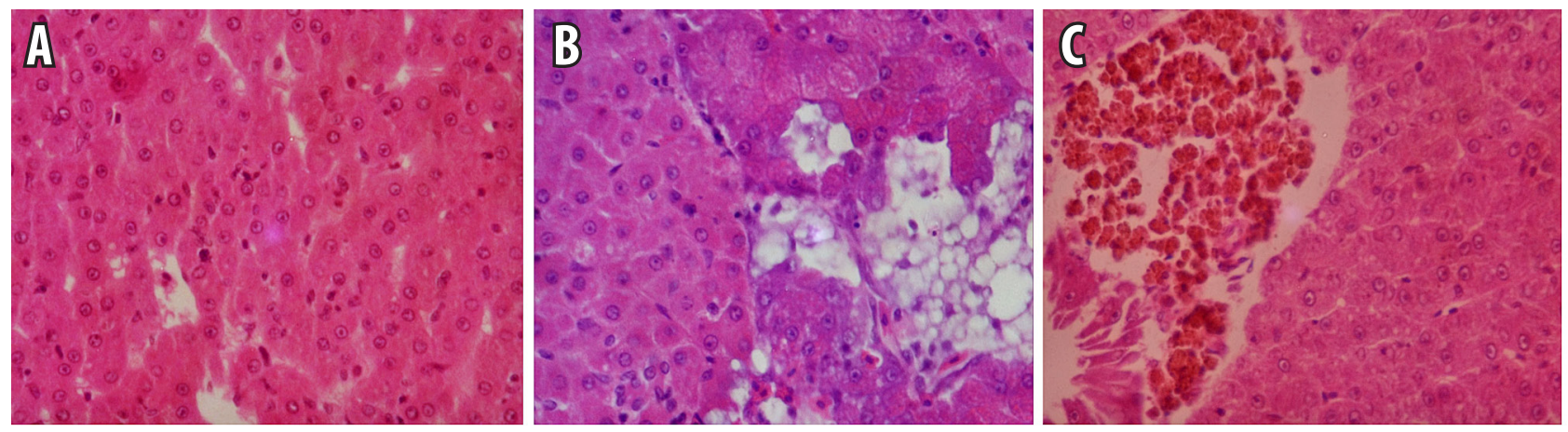

Fig. 3. A, liver histology of Chrysichthys nigrodigitatus showing no alteration, minimal vacuolation, sparse biliary duct numbers, and normal arrangement of hepatic cords. B, vacuolar degeneration of hepatocytes in liver tissue of C. nigrodigitatus. C, bile stains in liver tissue of C. nigrodigitatus.

\section{Histopathology of liver of C. nigrodigitatus}

Microscopic examination of liver of C. nigrodigitatus from Epe Lagoon revealed no alteration in liver ultrastructure (Fig. 3A). Liver of C. nigrodigitatus from Lagos Lagoon showed vacuolar hepatocellular degeneration in two samples (Fig. 3B), while the examination of liver of $C$. nigrodigitatus from Ologe Lagoon indicated bile stains in two samples (Fig. 3C).

\section{Discussion}

Chrysichthy nigrodigitatus has nutritional and commercial importance in Nigeria; therefore it is essential to assess the influence of water contamination on the health of the fish species. The final sink for many contaminants is the aquatic environment (Stegeman, Hahn 1994) and in this environment, contaminants are partitioned between water column, bottom sediments and biota. In this study, the low level of heavy metals in water compared to sediments and fish tissues is consistent with previous reports (Obasohan et al. 2006; Olowu et al. 2010). Heavy metals were present in water samples from Epe and Ologe lagoon in the concentration order $\mathrm{Zn}>\mathrm{Ni}>\mathrm{Pb}$. $\mathrm{Pb}$ in water samples from Lagos and Ologe lagoon and $\mathrm{Ni}$ in samples from the three lagoons exceeded the WHO recommended water quality guidelines (UNEPGEMS 2006). Sediments have been reported to form the major sink of heavy metals in aquatic system (Olowu et al.2010) and this may make the sediments hazardous to benthic organisms. The order of heavy metals in sediments was $\mathrm{Zn}>\mathrm{Pb}>\mathrm{Ni}$. C. nigrodigitatus is a bottom dwelling fish and a benthic feeder and may be at more risk of exposure to heavy metals in sediments than in water. Fish have the ability for uptake and accumulation of heavy metals in their muscles and it is important to screen tissue levels to ensure that these metals are not transferred to man through food.

The concentrations of $\mathrm{Pb}$ and $\mathrm{Cd}$ in muscle of silver catfish samples from Lagos and Ologe lagoon respectively and concentration of $\mathrm{Ni}$ in fish samples from both lagoons were higher than the Food and Agriculture Organisation
(FAO) maximum allowable limits; $\mathrm{Pb} 0.5 \mathrm{mg} \mathrm{kg}^{-1}$, Cd 0.05 $\mathrm{mg} \mathrm{kg}^{-1}$ and $\mathrm{Ni} 0.1 \mathrm{mg} \mathrm{kg}^{-1}$ (FAO 1983). One may conclude that consuming the fish samples analyzed may constitute a health hazard, since the fishes contained trace metals above the FAO limits.

The condition factor (CF) of a fish, often used to depict the well-being of a fish, can also serve as a first-level screening test to identify pollutant exposure and effect (Van der Oost et al. 2003). It was observed that the size (length and weight) of $C$. nigrodigitatus caught by fishermen at Ologe Lagoon were smaller than in Lagos lagoon while at Epe Lagoon the quantity and size were bigger. The mean condition factor of 1.10 (Epe lagoon) and 1.04 (Lagos and Ologe lagoon) obtained for samples of C. nigrodigitatus were lower than those reported by Atobatele and Ugwumba (2011; 2.76 to 3.03$)$, but higher than the values reported by Offem et al. (2009; 0.996) for silver catfish sampled from Aiba Reservoir Iwo and Cross River respectively in Nigeria. Poor environmental conditions may affect the condition factor of fish (Haruna, Bichi 2005). The low condition factor values recorded for Lagos and Ologe Lagoon suggest that the fish may be stressed by the deteriorating water quality caused by influx of a complex mixture of domestic and industrial wastes containing heavy metals. Decrease in the condition factor has being linked to loss of appetite and feeding behaviour of fish. Heavy metals have been suggested to affect the condition factor of fishes (Authman 2008).

Cd was reported to cause loss of appetite in rainbow trout (Mcgeer 2000) while Naz et al. (2013) reported decrease in average weight, fork and total lengths, condition factor and feed intake in Catla catla, Labeo rohita, Cirrhina mrigala, Ctenopharyngodon idella and Hypophthalmichthys molitrix exposed to sub-lethal concentrations of $\mathrm{Zn}, \mathrm{Pb}$, and $\mathrm{Mn}$ mixture.

Once absorbed, heavy metals are localized by binding with biologically active constituents like lipids, amino acids and proteins in tissues and organs. Higher concentration of heavy metals in liver and gill compared to muscle tissue of C. nigrodigitatus from the three lagoons were in agreement 
with earlier reports (Canli, Kalay 1998; Dural et al. 2006; Alhas et al. 2008; Ayotunde et al. 2012). Uptake of heavy metals in fish occurs through diffusion facilitated absorption in gills, which are in direct contact with water (Oguzie 1996). Cd was present in the fishes analyzed although it was not detected in water and sediments. This suggests that the fishes would have been exposed to the metal some time in the past and shows the importance of incorporating fish biomonitoring in the assessment of water quality. The BAF and BSAF showed that liver had higher metal load than other organs, relative to water and sediments. In fish, liver is the organ most commonly involved in the detoxification of foreign compounds (Van der Oost et al., 2003) and metals like $\mathrm{Zn}, \mathrm{Cu}$, and $\mathrm{Cd}$ to bind to metallothioneins in the liver during the detoxification process (Das 2006). Low levels of metals in tissues may be due to little blood supply to the muscular tissue (Shenouda 1992).

Metals can induce oxidative stress and assessment of antioxidant activities in fishes can indicate exposure to heavy metals in the aquatic environment (Livingstone 2003). TBARS concentration, and SOD and CAT activity in liver of C. nigrodigitatus obtained from Lagos and Ologe lagoon did not differ significantly from these in samples from Epe Lagoon, however GSH concentration in liver specimens from Lagos lagoon was higher compared to specimens from Ologe lagoon. The depletion of GSH concentration in liver of $C$. nigrodigitatus samples from Ologe and Epe Lagos lagoon may be linked to the $\mathrm{Pb}, \mathrm{Ni}$ and $\mathrm{Zn}$ in the liver. $\mathrm{Pb}, \mathrm{Cd}$ and $\mathrm{Ni}$ have electron-sharing affinities that could result in covalent attachment between them and sulfhydryl groups of GSH, which could result in GSH depletion, leading to the production of reactive oxygen species (Bondy 1996; Meister 1988; Quig 1998). Most heavy metals facilitate oxidative stress, yet zinc appears to act as a membrane stabilizer and prevents the formation of reactive oxygen species through protection of sulfhydryl groups against oxidation and displacement of redox metal ions from site-specific loci (Bray, Bettger 1990; Stohs, Bagchi, 1995). Hence, given that the highest concentration of zinc was found in water and sediments from Lagos lagoon, it is probable that GSH concentration in liver of fishes obtained from the lagoon was least depleted due to the protective effects of zinc.

Histopathological biomarkers are valuable indicators of the general health of fish and mirror the effects of exposure to pollutants (Hinton et al. 1992). Heavy metals have been suggested to cause histopathological alterations in liver of fishes. The results of microscopic examination of liver specimens from Lagos and Ologe Lagoon were consistent with the findings of Olarinmoye et al. (2009) in which liver of C. nigrodigitatus from Lagos lagoon showed several alterations including vacuolar hepatocellular degeneration and hepatic necrosis. Liver degeneration and necrosis due to exposure to $\mathrm{Ni}$ and $\mathrm{Cd}$ was observed in oriental sole (Euryglossa orientalis) and deep flounder (Psettodes erumei) caught from the north coast of the Persian Gulf (Khoshnood et al. 2010).

\section{Concusions}

The study showed the negative effects of contaminants containing heavy metals discharged into the lagoons and accumulation of $\mathrm{Pb}, \mathrm{Cd}, \mathrm{Ni}$ and $\mathrm{Zn}$ by $\mathrm{C}$. nigrodigitatus relative to water and sediments. Low condition factor, GSH depletion and histology alterations in liver may be linked to the bioaccumulation of heavy metals by $C$. nigrodigitatus. The biological responses of $C$. nigrodigitatus may be useful indicators of aquatic pollution and further research on the possible use of $C$. nigrodigitatus as a model organism for routine monitoring of aquatic ecosystem is recommended.

\section{References}

Adebola O.O. 2011. Iron, zinc, cadmium and lead in Chrysichthys nigrodigitatus from Ologe lagoon, southwest, Nigeria. Eur. J. Sci. Res. 73: 163-170.

Ajao E.A. 1996. Review of the state of pollution on the Lagos lagoon. NIOMR Tech. Paper No 106.

Alhas E.S, Oymak H. Karadede 2008. Heavy metal concentrations in two barb, Barbus xanthopterus and Barbus rajanorum mystaceus from Ataturk dam lake Turkey. Environ. Monit. Assess. 48: 11-18.

Anetekhai M.A., Akin-Oriola G.A., Jimoh A.A., Akintola S.L., Kumolu-Johnson C.A. 2003. Preliminary report on fish and fisheries of Ologe lagoon, Lagos, Nigeria. Third international conference of the Pan-African fish and fisheries association. Cotonou, Benin Republic. 10th - 14th November, 1-11.

Atobatele O.E., Ugwumba A.O. 2011. Condition factor and diet of Chrysichthys nigrodigitatus and Chrysichthys auratus (Siluriformes: Bagridae) from Aiba reservoir, Iwo, Nigeria. Rev. Biol. Tropical 59: 1233-1244.

Authman M.M.N. 2008. Oreochromis niloticus as a biomonitor of heavy metal pollution with emphasis on potential risk and relation to some biological aspects. Global Veterinaria 2: 104-109.

Ayotunde E.O., Offem B.O., Bekeh F.A. 2012. Heavy metal profile of water, sediment and freshwater catfish, Chrysichthys nigrodigitatus (Siluriformes: Bagridae), of Cross River, Nigeria. Am. Euras. J. Toxicol. Sci. 2: 196-202.

Busacker G.P., Adelman I.R., Goolish E.M. 1990. Growth. In Schreck C.B., Moyle P.B. (eds) Methods for Fish Biology. American Fisheries Society, Bethesda, pp. 363-387.

Canli M., Kalay M. 1998. Levels of heavy metals (Cd, Pb, Cu, $\mathrm{Cr}$ and $\mathrm{Ni}$ ) in tissue of Cyprinus carpio, Barbus capito and Chondrostoma regium from the Seyhan River, Turkey. Turkish J. Zool. 22: 149-157.

Chinni S., Yallapragda R. 2000. Toxicity of copper, cadmium, zinc and lead to Penaeus indicus post larvae: effects of individual metals. J. Environ. Biol. 21: 255-258.

Das K., De Groof A., Jauniaux T., Bouquegneau J. 2006. Zn, Cu, $\mathrm{Cd}$ and $\mathrm{Hg}$ binding to metallothioneins in harbour porpoises Phocoena phocoena from the southern North Sea. BMC Ecol. 6: 2.

Dural M., Goksu M., Ozak, D. 2006. Bioaccumulation of some 
heavy metals in different tissues of Dicentrachus labrax L., 1758, Sparus aurata L., 1758 and Mugil cephalus, 1758 from the Camlik Lagoon of the eastern coast of Mediterranean (Turkey). Environ. Monit. Assess. 118: 65-74.

Edokpayi C.A., Uwadiae R.E., Asoro A.O., Badru A.E. 2008. Phytomacrofauna arthropod associated with the roots of water hyacinth (Eichhornia crassipes) in Epe lagoon southern Nigeria. Ecol. Environ. Conserv. 14: 241-247.

Ellman G.L. 1959. Tissue sulphydryl groups. Arch. Biochem. Biophys. 82: 70-77.

Food and Agriculture Organization (FAO) 1983. Compilation of legal limits for hazardous substances in fish and fishery products. FAO Fishery Circular, No. 464, pp:5-100

Farombi E.O., Adelowo O.A., Ajimoko Y.R. 2007. Biomarkers of oxidative stress and heavy metal levels as indicators of environmental pollution in African catfish (Clarias gariepinus) from Nigeria Ogun River. Int. J. Environ. Res. Publ. Health. 4: 158-165.

Haruna M., Bichi A.H. 2005. Studies on length-weight relationship and condition factor of the cichlids of Tomas Lake, Kano, Nigeria. Biol. Environ. Sci. J. Trop. 2: 94-100.

Hinton D.E., Baumann P.C., Gardner G.C., Hawkins W.E., Hendricks J.D., Murchelano R.A., Okihiro M.S. 1992. Histopathologic biomarkers. In: Huggett R.J. et al. (eds) Biomarkers: Biochemical, Physiological and Histological Markers of Anthropogenic Stress. Lewis Publishers, Chelsea, pp. 155-210.

Holmlund C.M., Hammer M. 1999. Ecosystem services generated by fish populations. Ecol. Econom. 29: 253-268

Khoshnood Z., Mokhlesi A., Khoshnood R.2010. Bioaccumulation of some heavy metals and histopathological alterations in liver of Euryglossa orientalis and Psettodes erumei along North Coast of the Persian Gulf. Afr. .J Biotechnol. 9: 6966-6972

Kumolu-Johnson C.A., Ndimele P.E., Akintola S.L., Jibuike C.C. 2010. Copper, zinc and iron concentrations in water, sediment and Cynothrissa mento (Regan, 1917) from Ologe Lagoon, Nigeria: a preliminary survey. Afr. J. Aquat. Sci. 35: 87-94.

Livingstone D.R. 2003. Oxidative stress in aquatic organism in relation to pollution and agriculture. Rev. Med. Veter. 154: 427-430.

Luna L.G. 1992. Histopathologic methods and color atlas of special stains and tissue artifacts. American Histolabs, Inc.

Magwere T., Naik Y.S., Hasler J.A. 1997. Effect of chloroquine treatment on antioxidant enzymes in rat liver and kidney. Free Radic. Biol. Med. 22: 321-327.

Mcgeer J.C., Szebedinszky C., Mcdonald D.G., Wood C.M. 2000. Effects of chronic sublethal exposure to waterborne $\mathrm{Cu}$, $\mathrm{Cd}$ or $\mathrm{Zn}$ in rainbow trout: ion-regulatory disturbance and metabolic costs. Aquat. Toxicol. 50: 231-243.

Naz S., Javed M., Tahir A. 2013. Assessing growth responses of fish exposed to heavy metals mixture by using regression analyses. Pakistan J. Zool. 45: 921-928.

Nichens W.G., Samuelson B. 1968. Formation of malondiahyde from phospholipid arachidonate during microsomal lipid peroxidation. Eur. J. Biochem. 6: 126-130.

Nriagu J.O., Jozef M., Pacynar J.M. 1988. Quantitative assessment of worldwide contamination of air, water and soils by trace metals. Nature 333: 134-139

Nubi O.A., Ajao E.A., Nubi A.T. 2008. Pollution assessment of the impact of coastal activities on Lagos lagoon, Nigeria. Sci. World J. 3: 83-88.
Obasohan E.E., Oronsaye J.A.O., Obano E.E. 2006. Heavy metal concentrations in Malapterurus electricus and Chrysichthys nigrodigitatus from Ogba River in Benin City, Nigeria. Afr. J. Biotechnol. 5: 974-982.

Obiakor M.O., Ezeonyejiaku C.D., Ezenwelu C.O., Ugochukwu G.C. 2010. Aquatic genetic biomarkers of exposure and effect in catfish (Clarias gariepinus Burchell, 1822). Am. Euras. J. Toxicol. Sci. 2: 196-202.

Offem B.O., Akegbejo-Samsons Y., Omoniyi I.T. 2009. Trophic ecology of commercially important fishes in the Cross River, Nigeria. J. Anim. Plant Sci. 19: 37-44.

Oguzie F.A. 1996. Heavy metals in fish, water and effluents of the lower Ikpoba River in Benin. Ph.D. Thesis, University of Benin, Benin City, Nigeria.

Olarinmoye O., Taiwo V., Clarke E., Kumolu-Johnson C., Aderinola O., Adekunbi F. 2009. Hepatic pathologies in the brackish water catfish (Chrysichthys nigrodigitatus) from contaminated locations of the Lagos lagoon complex. Appl. Ecol. Environ. Res. 7: 277-286.

Olowu R.A., Ayejuyo O.O., Adewuyi G.O., Adejoro I.A., Denloye A.A.B., Babatunde A.O., Ogundajo A.L. 2010. Determination of heavy metals in fish tissues, water and sediment from Epe and Badagry Lagoons, Lagos, Nigeria. E-Journal Chem. 7: 215-221

Oribhabor B., Ezenwa B. 2005. Inventory of fisheries and fishes of the Lagos lagoon, Lagos Nigeria. Tropical Freshwater Biol. 14: 19-36.

Payne J.F., Fancey L.L., Rahimtula A.D., Porter E.L. 1987. Review and perspective on the use of mixed-function oxygenase enzymes in biological monitoring. Comp. Biochem. Physiol. 86C: 233-245.

Powers D.A. 1989. Fish as model systems. Science 246: 352-358.

Schwarzenbach R.P., Escher B.I., Fenner, K., Hofstetter T.B., Johnson C.A. 2006. The challenge of micropollutants in aquatic systems. Science 313: 1072-1077.

Shenouda T.F., Abou-Zaid A.A., Abada A. 1992. Water pollution and bioaccumulation of the highly pollutant agents in different organs of Oreochromis niloticus near Kafr El-Zayat. J. Zool. Proc. Zool. Soc. 23: 12-25.

Sinha K.A. 1972. Colometric assay of catalase. Anal. Biochem. 47: 389-394.

Skouras A., Broeg K., Dizer H., Von Westernhagen H., Hansen P., Steinhagen D. 2003. The use of innate immune responses as biomarkers in a programme of integrated biological effects monitoring on flounder (Platichthys flesus) from the southern north Sea. Helgol. Mar. Res. 57: 190-198

Stegeman J.J., Hahn M.E. 1994. Biochemistry and molecular biology of monooxygenase: current perspective on forms, functions, and regulation of cytochrome P450 in aquatic species. In: Malins D.C., Ostrander G.K. (eds) Aquatic Toxicology Molecular, Biochemical and Cellular Perspectives. Lewis Publishers, CRC Press, Boca Raton, pp. 87-206.

Uaboi-Egbenni P.O., Okolie P.N., Martins O., Teniola O. 2010. Studies on the occurrence and distribution of heavy metals in sediments in Lagos Lagoon and their effects on benthic microbial population Afr. J. Environ. Sci. Technol. 4: 343-351.

UNEPGEMS 2006. United Nations Environment Programme Global Environment Monitoring System/ Water Programme (Water Quality for Ecosystem and Human Health). ISBN 92-95039-10-6. Available online at http://www.env-edu.gr/ Documents/Water\%20Quality\%20For\%20Ecosystems\%20 
and\%20Human\%20Health.pdf

Van der Oost, Beyer J., Vermeulen N.P.E. 2003. Fish bioaccumulation and biomarkers in environmental risk assessment: a review. Environ. Toxicol. Pharmacol. 13: 57-149
Zelikoff J.T., Raymond A., Carlson E., Li Y., Beaman J.R., Anderson M. 2000. Biomarkers of immunotoxicity in fish: from the lab to the ocean. Toxicol. Lett. 112/113: 325-331. 